\title{
Management of Learning from Home in Elementary School
}

\author{
Ispurnatin $^{1}$, M. Ali Sibram Malisi ${ }^{*}$ \\ ${ }^{1}$ Teacher of SDN I Mentawa Hilir Sampit, East Kotawaringin, Central Kalimantan, Indonesia. \\ ${ }^{2}$ Doctor of Islamic Education, State Institute for Islamic Studies (IAIN) Palangka Raya. \\ *Corresponding Author: M. Ali Sibram Malisi, Doctor of Islamic Education, State Institute for Islamic \\ Studies (IAIN) Palangka Raya, Indonesia.
}

\begin{abstract}
This paper aims to analyze the management of learning from home (LFH) conducted in elementary schools. It is known to have been running for a year. A separate challenge regarding arrangements ranging from planning, organizing, implementation and controlling. That management functions become a parameter in looking at the process and success of learning management from home that has been implemented.

The research method used qualitative descriptive type with data collecting techniques using observation, interview and documentation. Furthermore, the subjects of the study were the Class Guardians, Teachers of Religious Education and Physical Education and Health Sports at SD Negeri I Mentawa Hilir Sampit, KotawaringinTimur, who became informants were parents and students.

The findings in the study are online distance learning with a synchronous learning model. In synchronous learning, students and teachers are in the same place at the same time. But, here is Synchronous learning of students and teachers participates in classes through the Whatsapp Group. In this learning where a group of students are all involved. Learning from home by creating learning tools in the form of videos, photographing textbooks and worksheets. Making agreements with parents on the availability of learning materials and making agreements about parents is obliged to provide assistance and attention to students. Learning follows the instructions in textbooks and student worksheets. Through the use of Whatsapp application teachers can send a wide variety of tasks, with various document formats, ranging from Ms. Word, Ms. Power Point, video links, voice messages, photographingand the like.
\end{abstract}

\section{INTRODUCTION}

School is an institution where students formally study and is a forum for students to determine the direction or steps they want to take and to determine the goals they want to achieve for the future. However, with the emergence of the covid-19 pandemic, there has never been any implementation of education conducted in schools of all levels. The Covid-19 pandemic is a health crisis that infects millions of people in more than 200 countries around the world and causes many deaths. (Ahmadi, 2020:2) The World HealtyOrganitation (WHO) has designated Covid_19 as a global pandemic. The Covid-19 pandemic affects almost all aspects of life, not least the educational aspect. In this condition, the role and position of the educational aspect is considered crucial. (Baktiar, 2016) Many countries decided to close schools, colleges and universities. Education is one of the sectors that is very impacted by the covid-19 outbreak. To break the chain of spread of the covid-19 outbreak in which students and educators can role as carriers and spreaders of the virus without symptoms, almost all countries prohibit learning activities in schools. School closures occurred in more than a dozen countries due to the Covid-19 outbreak, including Indonesia. The government's action by issuing a circular (SE) from the Minister of Education and Culture is addressed to governors and regents / mayors throughout Indonesia. This document was circulated primarily to consider the birth and mental health of students, teachers and all school residents in the midst of the Covid-19 threat.

School is an institution where students formally study and is a forum for students to determine the direction or steps they want to take and to determine the goals they want to achieve for the future. However, with the emergence of the covid-19 pandemic, there has never been any implementation of education conducted in schools of all levels. The Covid-19 pandemic is a health crisis that infects millions of people in more than 200 countries around the world and causes many deaths. (Ahmadi, 2020:2)The World Healty Organitation (WHO) has designated Covid_19 as a global pandemic. The 
Covid-19 pandemic affects almost all aspects of life, not least the educational aspect. In this condition, the role and position of the educational aspect is extremely important. (Baktiar, 2016)Many countries decided to close schools, colleges and universities. Education is one of the sectors that is very impacted by the covid-19 outbreak. To break the chain of spread of the covid-19 outbreak in which students and educators can role as carriers and spreaders of the virus without symptoms, almost all countries prohibit learning activities in schools. School closures was done in more than a dozen countries due to the Covid-19 outbreak, including Indonesia. The government's action by issuing a circular (SE) from the Minister of Education and Culture is addressed to governors and regents / mayors throughout Indonesia. This document was circulated primarily to consider the birth and mental health of students, teachers and all school community in the midst of the Covid-19 threat.

In the context of the Circular letter of the Minister of Education and Culture (Mendikbud) Republic of Indonesia Number 4 of 2020 concerning the Implementation of Education Policy in the Emergency Period of The Spread of Corona Virus Disease (COVID-19), this document was circulated primarily to consider the birth and mental health of students, teachers and all school residents in the midst of the threat of Covid-19. Central Kalimantan Governor's Decree Number: 9188.44/8/2020 concerning Emergency Response Status of Corona Virus Disease (COVID-19) In Central Kalimantan Province in 2020.

The Governor of Central Kalimantan has signed Decree Number: 443.1/26/DISDIK containing provisions on the Covid-19 Pandemic Emergency Response Status Protocol in the Education Office environment of Central Kalimantan Province, Palangkaraya, Thursday, March 26, 2020. Then came the Decree of the Regent of East Kotawaringin Number: 421.2/2063/Skrt/2020 Year 2020 concerning the Implementation of Education in the Emergency Period of The Spread of Corona Virus Diseases 2019 (Covid-19) East Kotawaringin District which was updated with the Decree of the Head of Education Office of East Kotawaringin District Number 421/2065/Skrt/2020 concerning The Extension of School Holiday Period addressed by the Head of Public/Private Junior High School to the Head of Public/Private Kindergarten, Head of Public/Private Elementary School, Head of Public/Private Elementary School, Head of Regional Coordination (KORWIL) subdistrict in East Kotawaringin Regency, among others: (1) National Examination (UN): UN Year 2020 was canceled, including the 2020 Skills Competency Test for Vocational High Schools; (2) The Learning Process shall be conducted from Home (LFH), Learning from Home through online/distance learning shall be conducted to provide a meaningful learning experience for students. Because of the importance of learning, in situations and emergencies even the learning process is still carried out. Mid-Year 2020.

Over time, home learning (LFH) initially requires adaptation for smooth learning. Students will find where boredom or lazy, this is due to learning techniques that are less interesting or unpleasant so as to cause ineffectiveness in learning for students, it can also be due to the lack of understanding of them to the materials provided. Learning from home (LFH) through online can actually be exciting with interesting techniques and teaching resources also to hone creativity. Home learning is also considered to have a greater impact on spending, namely for credit and internet connection (Purwanto et al. 2020), as well as demanding parents to be literate of technology in order to support the learning process at home. According to research from Khasanah (2020) at first many parents reject online learning for their children, because they are each with technology. But over time, people began to receive this online learning (Ihsanuddin, 2020; Shereen et al., 2020).

Thus, this paper aims to analyze the management of learning from home (LFH) conducted by elementary schools. It is known to have been running for a year. A separate challenge regarding arrangements ranging from planning, organizing, implementation and supervision. That management functions become a parameter in looking at the process and success of learning management from home that has been implemented.

\section{LITERATURE REVIEW}

\subsection{Management Functions}

Management functions are a series of stages of activities or work until the end of achieving the objectives of activities or employment. Thus the management will help in the implementation of an activity because before the implementation of the activity or work is made a plan to know what stages it will go through. (Manulang, 2015: 27)According to Robbins and Coulter, the management function can be summarized into four, namely: 1) Planning, planning is a management function that involves 
setting goals, setting strategies used to achieve those goals and developing plans to integrate and coordinate the activities to be carried out; 2) Organizing, that is a management function that involves organizing and structuring the work of what is done and who is doing the work to achieve the objectives of the organization; 3) Actuiting, implementation is the process to achieve the objectives that serve to realize planning and organizing accompanied by the provision of motivation, direction and influence to all members of the group in order to work consciously and willingly; 4) Controlling, supervision is a management function that includes supervision, comparison and correcting work performance to ensure all activities run as planned (Robbins, Stephen P, and Mary Coulters, 2012: 9).

With a little unraveling Siagian shows the functions of management include: 1) Planning, it can be defined as the whole process of thinking and determining carefully about things to be done in the future in order to achieve the goals that have been set; 2) Organizing, it is the whole process of grouping people, tools, tasks, responsibilities and authorities in such a way as to create an organization that can be moved as a unity in order to achieve a predetermined goal; 3) Motivating, that can be defined as the whole process of giving encouragement to subordinates in such a way that they want to work sincerely in order to achieve organizational goals efficiently and economically; 4) Controlling,that is the process of observing the implementation of all organizational activities to ensure that all the work that is being carried out goes according to the predetermined plan; 5) Assessment is the last organic function of administration and management. The definition is the process of measuring and comparing the results of the work that is actually achieved with the results that should be achieved. (Hasibuan, 2005:3)

Based on the above opinions from several expert opinions, it can be concluded that management functions are planning, organizing, motivating, actuating and controlling, evaluation that aims to carry out activities so that a goal is achieved effectively and efficiently. In this paper, the author limits only to planning, organizing, implementing and controlling.

\subsection{The Concept of Learning From Home (LFH)}

Learning from home (LFH) is a learning process conducted by students and teachers in their homes. With this LFH, it is expected to break the chain of spread of Covid-19 disease. During LFH students are encouraged to keep doing all activities at home and implement clean and healthy living behaviors. By staying active from home, students will automatically keep their distance from others (physical distancing) and avoid crowds (social distancing).

Learning patterns during LFH has changed. If the previous teaching and learning activities were done face-to-face, it becomes distance learning. In this lesson, the teacher was not present in one room with the students but took place in a different place. Distance learning is done with the help of media in the form of electronic devices handphone android connected through the internet network. This learning is called online learning. Online learning is commonly called e-learning, derived from the word electronic and learning which means learning using electronic equipment. Stockley (2010) in Chaeruman (2013: 400) defines e-learning as the delivery of learning programs, training or education by using electronic means such as computers or other electronic devices such as mobile phones to provide training or education. Stockley asserts that the word "e" refers to the use of electronic means for learning.

The application of online learning that prioritizes self-learning at home requires adequate computer and internet facilities and infrastructure. In addition, it must also be supported by learning methods, learning resources in the form of books and other learning resources as well as the active role of parents at home. The application of online learning that prioritizes self-learning at home requires adequate computer and internet facilities and infrastructure. In addition, it must also be supported by learning methods, learning resources in the form of books and other learning resources as well as the active role of parents at home.

The Ministry of Education and Culture (MOEC) reaffirmed that educators who are still giving lessons online should pay attention to the guidelines for home from learning (LFH). The application of online learning has hampered the learning process because some senior teachers are unable to apply the internet or stutter technology. Therefore, there needs to be mentoring and learning training through online. During the Covid-19 pandemic the learning process takes place in a unidirectional manner, so that students and teachers can use e-learning paltform facilities such as the Teachers Room, Google Clasroom, Google Meet, and Zoom. (Purwanto, et al., 2020). The LFH Guidelines, according to 
the Bureau of Cooperation and Public Relations MOEC based on the Circular letter of the Secretary General of the Guidelines for The Implementation of Learning from Home (LFH) in the Emergency Period of the Spread of Covid-19. " The circular is based on Circular Letter (SE) of the Minister of Education and Culture No. 4 of 2020 concerning the Implementation of Education Policy in the Emergency Period of The Spread of Covid-19” (mediaindonesia.com, Kamis, 11/11/2020).

This aims to ensure the fulfillment of children's right to obtain educational services during the Covid19 Outbreak, protect the citizens of the education unit from the adverse effects and transmission of Covid-19, prevent the spread and transmission of Covid-19 in the education unit and ensure the fulfillment of psychological support for educators, students and parents / guardians. Distance learning at home means parents have an important role to play in monitoring children's learning activities during school. Parents should wisely apply the rules so that the child is disciplined to learn at home. Discipline that is not applied during home study, it is feared that will make the child far behind compared to other students when the school starts to return to normal.Here are some ways that children are disciplined to learn at home:

1) Explaining the Situation. Explain the current situation to children about social distancing and activities at home. Give understanding that children still have to learn at home. Explain that studying at home is one form of prevention of coronavirus transmission. Crowded places such as schools and other public spaces may increase the potential for transmission of the Covid-19 virus.2)Active consultation with Teachers.Personal Growth Psychologist Gracia Ivonika suggests that parents always actively consult with teachers in schools. Ask the teacher about the material the child should learn, the learning methods, and the tasks to be done. Also tell the child's development during home study so that the teacher can anticipate the next learning step. 3) Making a regular schedule.School holidays don't mean lazing around. Explain to the child the situation that the school continues and is only moved home. Explain that the children are not actually off school but studying at home. Here, parents may make it flexible but regular schedules such as school activities. 4) Learning and cooperating. The activities of parents who have to work from home can be combined with learning with children. Children will feel fairer and encouraged to learn when parents also participating. 5) Guiding children to learn. Also help the child to understand the material studied. Explain well to the child what parents understand. If you don't understand the learning materials, feel free to ask the teacher or find the right source to explain the material to the child. 6) Taking advantage of online learning media. Parents may also apply online learning media that has been provided by the Ministry of Education and Culture as well as a number of institutions that provide free access. Make the most of this learning method to get videos and images according to the material the child needs.Create a comfortable learning atmosphere. 7) Making a comfortable atmosphere for work and study at home. Doing activities at home means having feel free and freedom to explore. Parents can invite children to study in the living room or yard of the house to get open air. Using additional objects such as pillows and preparing snacks can also be done so that the child feels at home learning. 8) Intersperse with fun activities. In order not to be boring, always prepare fun activities with children. This activity can also be a gift when the child completes a task or material. Fun activities such as playing video games and watching movies. Don't forget to invite your children to do physical activities and exercise during their activities at home (Pratiwi, 2020).

\subsection{The Regulations of Learning from Home in Indonesia}

In March 2020, Minister of Education and Culture NadiemMakarim issued Circular Letter (SE) Number 4 of 2020 concerning the Implementation of Education Policy in the Emergency Period of The Spread of Covid-19. One of the points of the SE is the question of learning from home remotely (online distance learning). The Ministry of Education and Culture Republic of Indonesia has released guidelines for implementing the Learning from Home (LFH) policy during the Covid-19 pandemic (Kemdikbud, 2020). It states teachers must facilitate students with online distance learning in accordance with the conditions and availability of learning tools and prepared learning plans, availability of time, conditions and agreements between students and parents. In addition, the implementation of the LFH policy especially for students at lower levels of education is recommended to get online parental assistance.

A special policy for school management was also issued by the Ministry of Education and Culture of the Republic of Indonesia, stating that schools can have the use of Flexible School Operational 
Assistance (BOS) and Educational Operational Assistance (BOP) with a view to meeting school needs during the Covid-19 outbreak such as buying internet quotas students so may create better result in distance teaching and learning (Permendikbud No. 20, 2020b). Moreover, not only policies in terms of school management, the Ministry of Education and Culture pays more attention to health protocols in conducting the teaching and learning process as stated in Permendikbud No. 3 (2020) on the prevention of the Covid-19 outbreak in the education unit. In particular, the regulations cover the need for schools to coordinate and communicate with local health officials, ensure the availability of hygiene and health facilities, monitor the presence of school elements especially when one is sick and related to respiratory problems, promote a healthy lifestyle, remind school elements to avoid direct physical contact such as shaking hands and cuddling, canceling all activities that are considered gathering many people inside or outside the school premises.

The Ministry of Education and Culture (MOEC) tinkered with education policy during the year of the covid-19 pandemic. It is noted that a number of education policy adjustments were made to address learning difficulties during the pandemic. One that is brave enough is to abolish the National Examination (UN). The abolition the UN is indeed an old discourse that has not been done. Since being appointed, Minister of Education and Culture NadiemMakarim immediately stated that he would replace it, but it turned out to take place faster due to the pandemic.

Learning from home begins. That same month, the government announced the national exam was cancelled. In addition, school exams do not need to measure the completion of the curriculum. Then, schools that have not conducted the exam can use the grades of the last five semesters to determine the graduation of students.

The New Student Admissions Mechanism (PPDB) also does not collect students and parents. PPDB achievement path based on accumulated score report card and other achievements. The Ministry of Education reallocated the higher education budget of Rp405 billion for the Education Hospital (RSP) of public and private universities. The cultural budget is allocated rp70 billion for Learning from Home through TVRI. Then, there is also the launch of the Teacher Sharing portal, relaxation of the use of School Operational Assistance (BOS) and Education Operational Assistance (BOP) for teacher honor payments, as well as online learning. Pandemic covid-19 makes the world of education, especially primary and secondary schools change the learning model. From the usual face-to-face to online distance learning (PJJ).

Since then, almost all schools from early childhood education (PAUD), elementary school (SD), junior high school (SMP) and high school (SMA) apply distance learning. However, there are many problems when distance learning conducted. Among others: Teachers do not understand how online learning, internet quota problems, students are charged many tasks, limited facilities such as gadgets and internet networks, and release a simplified curriculum. After eight months of distance learning, the government began to work on opening schools. So that face-to-face learning can be held again. Through a Joint Decree (SKB) 4 Ministers allow schools located in green and yellow zones to roll out face-to-face with strict health protocols. Schools that want to hold TPM must meet the predetermined conditions. Until entering the new school year 2021 there are still few schools that open schools. In fact, some are back closed after there are teachers who are positive covid-19. (www.medcom.id)

\section{Method Of Research}

This study used qualitative approach with descriptive design, to illustrate the obstacles of online learning in Banjarnegara. The research object is elementary school teachers in Sampit Regency. The research subjects were grade I teachers, religious subject teacher and phsycal education (PJOK) subject teacher at State Elementary School (SDN) I Sampit East Kotawaringin. Data collection techniques were done by interviewing. Interview techniques are included in unstructured interview techniques and contain only the core of management Learning from Home (LFH). Beside from interview, dataalso obtained from observation and Whatsapp record.Then, it was analyzed using the concept of Miles and Huberman through reduction, display data and conclusion.

\section{RESUlt AND Discussion}

Planning of Learning from Home (LFH).This Learning from Home (LFH) activity is expected to support the distance learning process and facilitate the dissemination of materials to students. Therefore, the learning process that is usually carried out in schools face-to-face with the father / 
mother of teachers and friends can not be done during this pandemic. Students are required to learn from home (LFH), teachers are also required to prepare learning tools that allow students to learn from home. This condition makes the teacher have to change his teaching and learning strategy. Choosing materials that suitable with the right situations and conditions, lesson materials that do not require interaction outside the home, the use of appropriate teaching methods and the behavior and attitude of teachers in managing the teaching and learning process is needed in learning during the home learning program (LFH). All of this is done to provide unlimited access to learning space and time to students during the Covid-19 emergency. The condition of students and teachers who cannot meet in person to maintain social distancing and physical distancing is what makes learning must be done through online distance learning. In which, we know there are terms synchronous learning and asynchronous learning. According to Chaeruman (2020), in synchronous learning, students and teachers are in the same place at the same time. It's similar to a face-to-face class. One example of synchronous learning is when students and teachers participate in the classroom through a web conference application, can use a variety of applications that contain features in it (zoom meeting, google class room, google meet and many more) all of this creates a virtual classroom. In this learning where a group of students are all involved.

In the context of planning, an interview the researcher conducted with a grade 1 teacher said: "in planning learning from home we create learning tools by making videos, photographing student textbooks and worksheets. Making agreements with parents on the availability of learning materials and making agreements about parents are obliged to provide assistance and attention to students, which we explained we created a whatsapp group with the name "Homeroom teacher of Grade I A" (interview, 2021). Before determining the application used, the teacher discusses with the parents to determine the application to be used, taking into account the ease of use and elementary school teachers in Sampit choose to use the Whatsapp application as a means of online learning.

From the observations was done by researchers, that teachers prepared learning equipment with what is available, try their own as much as possible such as mobile phones, laptops. The availability of internet or Wifi facilities has been provided by the school. Teachers conducted learning activities in schools, present as in school before the covid-19 pandemic. They prepared various assignments for students according to the Student Worksheets that are already available in the worksheet (LKS) book (observation, 2021).

Thus, learning in schools is planned using synchronous learning that is only using whatsapp group, between teachers and students meet at one time but does not use the google meet or zoom clouds meeting application. This is likely because elementary school students are still not capable to use these applications. Online learning application tools require a variety of platforms that are easy, inexpensive, and allow for the achievement of learning objectives. Teachers carry out learning to students virtually using whatsapp on smartphones. The learning activity begins when the teacher gives an assignment through whatsapp and then the student collects the assignment in the form of an image/voice note/video. Online learning can only be done for students who have a smartphone / laptop, but not all parents are able to operate smartphones and do not have smartphones (Alfiah, et.al., 2020)

Organizing in Learning from Home ( $\mathrm{LFH}$ ). Organizing can be said to be a "vein" for an entire organization or institution. So it is very influential for all organizations or institutions including educational institutions (Burhanuddin, 1994). Organizing is a continuation of the planning function of a management system. Organizing in home learning (LFH) needs to be done.

Through interview and observation with grade I A homeroom teacher, researchers found that teachers organized learning following instructions in textbooks and student worksheets. Then the teacher prepared a video with footage of about 5-10 minutes. As for those related to daily assignments, the teacher made direct writing instructions on how to answer through whatsapp group. (interview and observation, 2021)

The organizing process in LFH includes:a) Reflecting the objectives and plans, the objectives of the LFH must be adapted to the vision, mission and objectives of the school; b) Establishing the main tasks, namely detailing all the work in the learning process, including teachers who have a major role in LFH, the duties of students and the involvement of parents. In organizing LFH disciplinary, school participation not only socializes about LFH, but also must build a sense of responsibility of the school 
community and include the parents so that in its implementation can run well and smoothly.

According to Mulyasa (2013: 139) the ability to organize materials consists of two stages, namely choosing learning materials and compiling learning materials. When learning takes place face-to-face, teachers are used to organizing learning. However, it is an obstacle, when learning takes place online. Teachers should choose extra learning materials so that there is no misconception between the teacher and the parent or student when studying the material. On the other hand, teachers should also look at the achievement of basic competencies that must be mastered by students. So the creation of materials when learning is done online must be conducted to the maximum.

Actuating in Learning from Home (LFH).Actuatingis the process to achieve the objectives that serve to realize planning and organizing with the provision of motivation, direction and influence to all members of the group in order to work consciously and willingly. (Burhanuddin, 2014) In the function of actuiting BDR should be carried out with full awareness by all involved: schools, teachers, students and parents / homeroom.

In observations made by researchers found that teachers make learning videos, the duration of the video is between 5 to 10 minutes. The content of the video directly conveyed by the teacher concerned in this regard is the homeroom teacher. The video, then shared through Whatsapp group owned by handphone Number of parents. In turn students are given instructions to answer questions and they answer by handwriting on paper or worksheet (LKS) then photographed and shared to whatsapp group that has been created by the homeroom teacher (Observation, 2021).

One of example of the task from teacher to the student every day (work day) has written in whatsapp group:

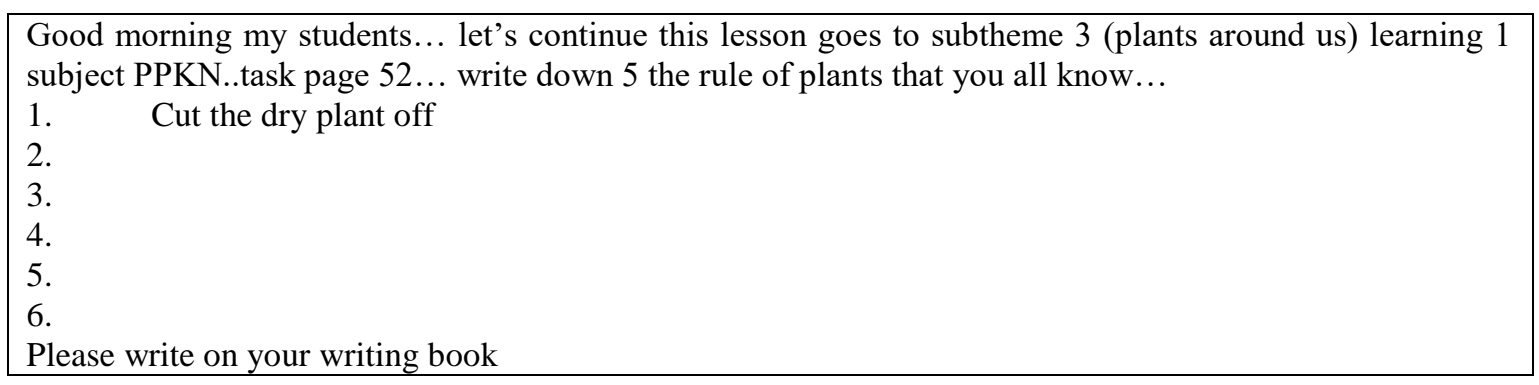

Picture1. The task from teacher in whatsapp document.

From the picture above, that "for homeroom teacher videos and photos are very effective, because it is flexible, I made a direct assignment I typed and shared to whatsapp group. Furthermore, children are instructed to answer directly in a striped paper book or Student Worksheet book, the answer is then photographed and shared to whatsapp group" (interview, 2021). In exploring the process of implementing Learning from the House. The researcher asked about the implementation, from an interview with a teacher of religious subject: "teaching elementary school students in my place, conducted presensi first through a special message on whatsapp group, my material conveyed briefly and densely. Then, I sent a short video as instructions and instructions on assigning tasks. whatsapp group, of course, directly responded by students assisted by their parents. Actually our goal as teachers, parents provide helping and attention instead of 100 percent of parents who answer when there is an assignment" (interview, 2021).

As the results of the study, the role of parents is very determining the implementation of learning from home, parents are required to accompany students to complete the tasks given by the teacher in accordance with the learning objectives. Online learning in the midst of the Covid-19 pandemic should be able to facilitate the student learning experience, but online learning is currently only giving students assignments to work on (Bilfaqih \& Qomarudin, 2015).

In the implementation of learning, teachers conduct several stages of learning implementation, among others: a. initial activities: opening lessons; b. Core activities: delivery of learning materials in accordance with the objectives and basic competencies set; c. closing the learning: in closing the lesson always give moral messages and remind to always obey health protocols to break the chain of transmission and spread of Covid-19.In its implementation both online distance learning and face-toface learning (offline) must still pay attention to the achievement of learning objectives. Referring to 
the opinions of Robert F. Mager, Kemp and Kapel, and Henry Ellington (in Uno, 2008) The purpose of learning is the behavior that students are about to achieve or that can be performed by students under certain conditions and competencies. A specific statement expressed in behavior or appearance embodied in writing to describe the expected learning outcomes. Statements are expected to be achieved as a result of learning. Meanwhile, Hamalik (2005) mentioned that the purpose of learning is a description of behavior that is expected to be achieved by students after learning.

Sudjana (2010) concluded the formulation of experts related to diverse learning objectives, but all point to the same essence, that: (1) the purpose of learning is the achievement of changes in behavior or competence in students after participating in learning activities; (2) the purpose is formulated in the form of a specific statement or description. Based on expert opinion on the definition and purpose of learning, it can be concluded that the purpose of learning is the estuary of the whole series of learning implementation carried out. The implementation of learning is a process that is arranged in such a way according to certain steps in order for the implementation to achieve the expected results. According to Bahri According to Bahri and Aswan Zain (2010:28) the implementation of learning is an activity of educational value, the educational value of coloring the interaction that occurs between teachers and students. Interactions of educational value due to the implementation of learning are directed to achieve certain objectives that have been formulated before the implementation of learning begins.

Controlling in Learning from Home (LFH).According to Koontz surveillance is, "Controlling is the measuring and correcting objectives of subordinates to assure that events conform to plans" (Koontz, 2010). In educational institutions supervision has an important role, because with the supervision can be known the results of the implementation of the work, what is in accordance with the plan and standards that have been determined or not. Supervision is a basic process that is essentially necessary how widespread and complex an organization is. While according to classical understanding, supervision is a process that is forced so that the implementation activities can be adjusted to the plan that has been set (Fatah, 1996). Supervision according to Siagian is the whole effort to strengthen the implementation of operational activities to ensure that the situation is in accordance with the plan that has been set. Such supervision is activities or actions to secure the plans and decisions that have been made and implemented. Supervision needs to be done to provide guidance, guidance or instructions to seek truth to the outcome of his work. Based on the explanation above, in the management of discipline of learners through learning from home (LFH), disciplinary has a very important role. With discipline allows students to organize, control themselves and succeed in the learning process as well as in their duties based on obedience.

To monitor students' learning progress, each teacher has a class group that is used to implement and monitor online learning. Through the use of whatsapp application teachers can submit a variety of tasks, with various document formats, such as Ms. Word, Ms. Power Point, video links, voice messages, etc. In addition to conducting online learning using whatsapp, the teacher also asked students to always make use of the home learning portal provided by the Ministry of Education through television broadcasts as a means of online learning.In supervising learning from home, every weekday morning at 7am of Sunday to Thursday as a classroom teacher conducts an online review by instructing children to type names and statements present in wa groups. If there are children who do not do presensi or do not pay attention then it becomes a teacher's note. As punishment is a lack in daily task assessment. Assessments conducted by teachers are accumulative, so every day is very decisive for the learning achievements of learners. On Fridays teachers of Religious subjects and on Saturdays pjok teachers. So that supervision through online presence is very effective to see the activeness and attention of students to learning from home. (Observation, 2021).

In addition, in the context of direct supervision by the homeroom teacher and subject teachers, when the midterm exams and final exams are conducted offline, but the exam schedule and procedures are still shared through whatsapp group and parents are asked to accompany in answering exam questions, but some of the questions of certain subjects are handed over by the teacher to the parents to be answered at home and returned tomorrow. The argument given by the teacher is that the meeting in the classroom must be in a short period of time (Observation and Interview, 2021).

Online learning activities will run well, if students are always supervised, both from teachers and parents. Facts in the field show that in the first week of online learning activities, parents pay full attention to their children. But in the second week onwards, supervision from parents began to decrease. This happened because at the same time, parents must also divide their time between 
working, taking care of the house and supervising the child's learning. So what happens is the teacher sends the assignment and the parents send the results of the child's work. Without any supervision in his studies. Parents argued that if the assignment had been left to the teacher, then the learning activity finishes on that day. This results in unidirectional communication, without any supervision in learning. Online learning results in students having to self-study materials, this is because teachers are unable to provide direct supervision (Alfiah et al., 2020). The role of parental supervision and attention to children in the online learning process is very important for the realization of optimal learning outcomes. Parents should be present in supervising and paying attention to the child both in the moments before learning begins, during learning, until after the learning is completed (Wardhani\&Krisnani, 2020).

Below is a picture showing the learning from home management model:

Planning: Students are required to learn from home, teachers are also required to prepare learning tools that allow students to learn from home, change their teaching and learning strategies, choose materials that suit situations and conditions, use appropriate teaching methods to implement teacher behaviors and attitudes in managing the teaching and learning process needed in it during the home learning program (LFH); organizing: carrying out organizing by assigning assignments and dividing tasks involving all school civity, principals, teachers, students and parent participation as well as school committees; actuating: in the implementation of discipline applying through habituation that focuses on learning, so that the class teacher who must arrange the learning scenario in his class, such as the initial activities, core activities, until learning closing; controlling: controlling is carried out by monitoring the implementation of disciplinary management of students in home learning conducted by teachers, with a follow-up. After the four stages are completed, in the hope of obtaining results for the improvement of discipline in learning at SDN I MentawaBaruHilirSampit, if obstacles are found, the solution will be sought, of course, to review the existing management functions.

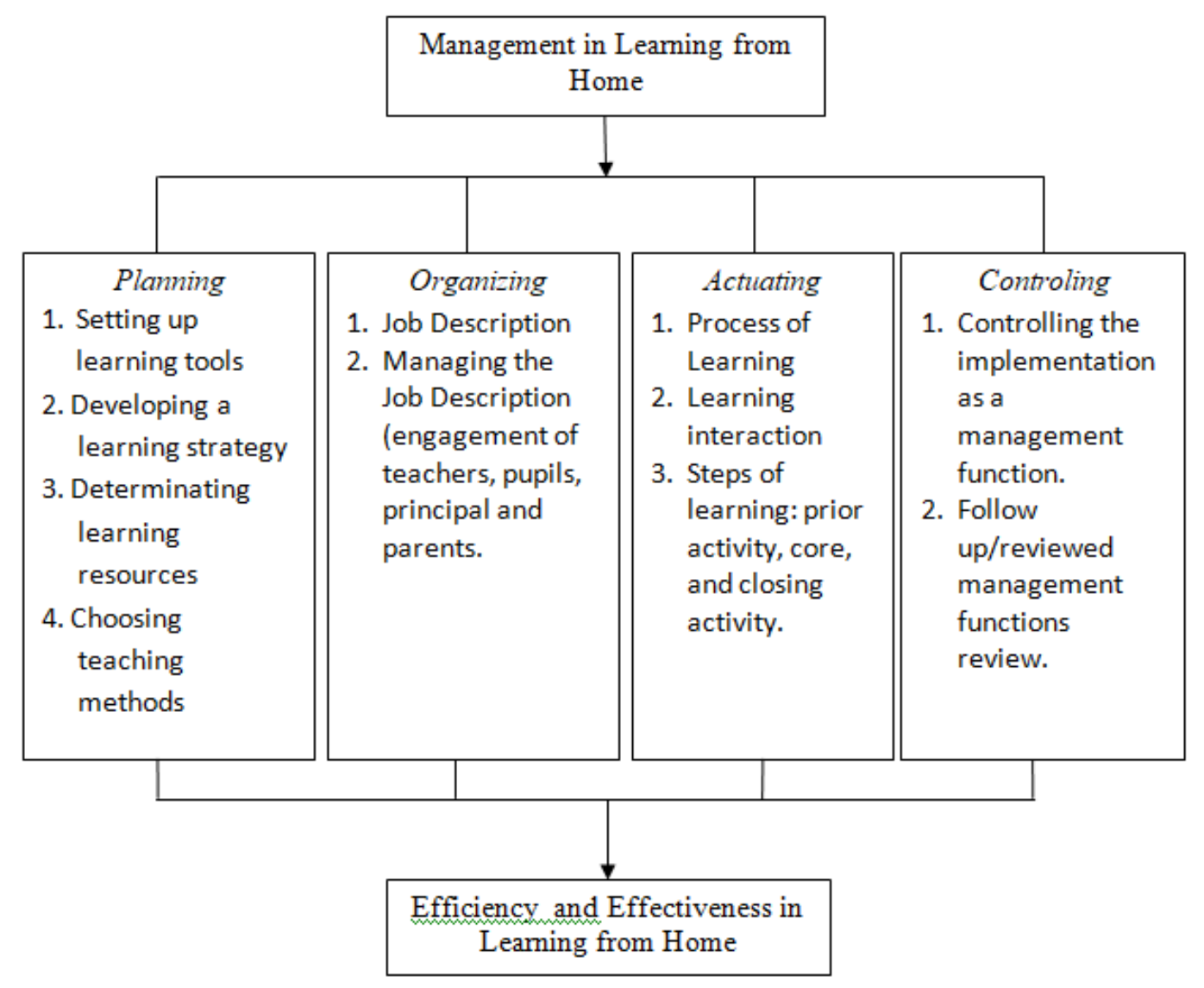

Picture2. The learning from home management model

\section{CONCLUSiON}

In an online learning, the study found that in synchronous learning, students and teachers were in the same place at the same time but not in the classroom. Synchronous learning of students and teachers participates through the app Whatsapp Group. In this learning where a group of students are all 
involved so management is required. Related to planning, learning from home by creating learning tools in the form of videos, photographing textbooks and worksheets of students. Making agreements with parents on the availability of learning materials and making agreements about parents is obliged to provide assistance and attention to students. In organizing the learning follow the instructions in the student's textbooks and worksheets. In the implementation, the teacher prepares a video with footage of about 5-10 minutes, the teacher then writes directly instructions on how to answer through wattshap group. between 5 and 10 minutes in length. The content of the video directly conveyed by the teacher concerned in this regard is the teacher's homeroom teacher. The video, then shared through Whatsapp group owned by handphone number of parents. In turn students are given instructions to answer questions and answer through handwriting on paper or worksheets (LKS) then photographed and shared to whattsapp group that has been created by the homeroom teacher. To monitor students' learning progress, each teacher has a class group that is used to implement and monitor online learning. Through the use of Whatsapp application teachers can submit a variety of tasks, with various document formats, ranging from Ms. Word, Ms. Power Point, video links, voice messages, etc. In addition to conducting online learning using Whatsapp, the teacher also asked students to always make use of the learning from home (LFH) portal provided by the Ministry of Education and Culture (MOEC) through television broadcasts as a means of online learning.

\section{REFERENCES}

[1] Ahmadi, Aulia Mustika Ilmiani. (2020).The Collaboration of Arabic Language Teaching Media During Covid-19 Pandemic: WhatsApp Gruop, Google Clasroom and Zoom Meeting.Dinamika Ilmu.

[2] Baktiar, T. (2016). Optimal Intervention Strategies For Cholera Outbreak By Education And Chlorination Iop Conference Series: Earth And Enviromental Science.

[3] Bilfaqih \& Qomarudin. (2015). Esensi Pengembangan Pembelajaran Daring. Yogyakarta; deepublish. ISBN 978-Nomor ISBN.

[4] Chaeruman, U. A. (2013). Merancang Model Blended Learning Designing Blended Learning Model.JurnalTeknodik Volume 17 Nomor 4, Desember 2013, Page 398-409 retrieved from https://Www. Researchgate.Net/Publication/332295723_Merancang_Model_Blended_Learning_Designing_Blended_Le arning_Model.

[5] Chaeruman. U. A, Pedati. (2020). ModelSistem Pembelajaran Blended, PanduanMerancang Mata Kuliah Daring, Spada Indonesia. Jakarta: DirektoratPembelajaranKemrisdikti. Jurnal Review PendidikanDasar: Vol 6, No 3, September 2020 Jurnal KajianPendidikandan HasilPenelitian http://journal.unesa.ac.id/ index.php/PD e-ISSN: 2460-8475.

[6] Djamarah, Syaiful Bahri dan Aswan Zain. (2010). StrategiBelajarMengajar. Jakarta: RinekaCipta.

[7] Fatah, Nanang. (1996).LandasanManajemenPendidikan, Bandung: RemajaRosdakarya.

[8] Hamalik, O. (2005). PerencanaanPengajaranBerdasarkanPendekatanSistem. Bandung: BumiAksara.

[9] Hasibuan, Malayu S.P. (2005). ManajemenSumberDayaManusia, Cet.IX, Jakarta: PT BumiAksara.

[10] https://www.medcom.id/pendidikan/news-pendidikan/nbwlBdRk-jejak-kebijakan-pendidikan-selamasatu-tahun-covid-19).

[11] https://www.medcom.id/pendidikan/news-pendidikan/RkjlAXVN-satu-tahun-covid-19-sekolah-masih-dirumah-saja?p=3)

[12] Koontz. (2010). Manajemen Function and Strategy, Tokyo: Mc. Graw Hill Kogakusha.

[13] Manulang. (2015). Dasar-DasarManajemen, Yogyakarta: GadjahMada University Press.

[14] Pratiwi, Winda. (2020). Jurnal: Cara agar Anak Disiplin Belajar Di Rumah. ccnindonesia.com. 2020316115617, h. 284.

[15] Prihatin, Eka. (2011). ManajemenPesertaDidik, Bandung: Alfabeta.

[16] Robbins, Stephen P, and Mary Coulters. (2012). Management, Eleventh Edition, United States Of America: Pearson Education Limited.

[17] Roshonah, A.F., Putri, S.A.D., \& ... (2020), Peran Orang TuadalamMembimbingAnak Selama Pembelajaran Daring di Rumah. ... NasionalPenelitian LPPM ..., 1-7. http://jurnal.umj.ac.id/index.php/ semnaslit/article/view/7904

[18] Sudjana, N. (2010). Penilaian Proses BelajarMengajar. Bandung: PT. RemajaRosdakarya.

[19] Uno, H.B. (2008).PerencanaanPembelajaran. Jakarta: PT BumiAksara.

[20] Wardhani, Tsaniya Zahra Yuthika, HettyKrisnani. (2020). Prosiding Penelitiandan Pengabdiankepada MasyarakatProsidingPenelitiandanPengabdiankepadaMasyarakat, Volume 7, pp 48-59; doi:10.24198/ jppm.v7i1.28256. 


\section{AUTHORS' BIOGRAPHY}

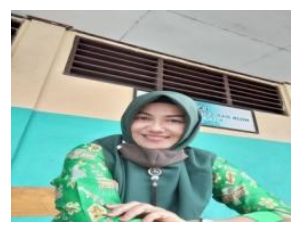

Ispurnatin, is a teacher of SDN I MentawaHilir, Sampit, Central Kalimantan, she pursues her research interest in Management of Education and Science of Education.

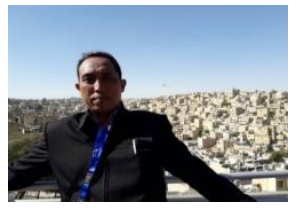

M. Ali Sibram Malisi, is a Doctor in Islamic Education, Lecturer in Postgraduate Studies of State Institute for Islamic Studies (IAIN) Palangka Raya, Central Kalimantan. Some International Experiences Shortcourse Research Methodology in Leiden University, Netherland, 2016; as a speaker of Republic of Indonesia Government's Delegation together with scholars from Gulf Countries, Europe, Asia, Africa in International Conference "Risalah Amman" in Amman, Jordan, 2017; as a Guest Lecturer and Speaker of Able People Conference in Ma'din Academy, Kerala, India, 2017; Postdoctoral Fellowship in Western Sydney University (WSU), Australia, 2018. His research interest include in Management of education, Science of Education, Islamic Education, Gender and Islam, Sociology of Education, and also study of Islamic Boarding School (Pesantren and madrasah).

Citation: Ispurnatin, M. Ali Sibram Malisi. "Management of Learning from Home in Elementary School" International Journal of Humanities Social Sciences and Education (IJHSSE), vol 8, no. 4, 2021, pp. 228-238. doi: https://doi.org/10.20431/2349-0381.0804019.

Copyright: (c) 2021 Authors. This is an open-access article distributed under the terms of the Creative Commons Attribution License, which permits unrestricted use, distribution, and reproduction in any medium, provided the original author and source are credited. 